\title{
Evidence for concentration of anthropogenic mercury in salt marsh sediments
}

\section{Evidencia de la concentración de mercurio antropogénico en sedimentos de salitrales}

\author{
C. Micaelo ${ }^{1 *}$ \\ M. Válega ${ }^{2}$ \\ C. Vale ${ }^{1}$ \\ E. Pereira ${ }^{2}$ \\ A. Duarte ${ }^{2}$ \\ I. Caçador $^{3}$ \\ ${ }^{1}$ Instituto de Investigação das Pescas e do Mar (IPIMAR) \\ Ave. Brasília \\ 1449-006 Lisboa, Portugal \\ *E-mail: micaelo@ipimar.pt \\ ${ }^{2}$ Departamento de Química \\ Universidade de Aveiro \\ 3810-193 Aveiro, Portugal \\ ${ }^{3}$ Instituto de Oceanografia, Faculdade de Ciências \\ Universidade de Lisboa \\ R. Ernesto de Vasconcelos, Campo Grande \\ 1700 Lisboa, Portugal
}

Recibido en noviembre de 2000; aceptado en noviembre de 2002

\begin{abstract}
Sediment cores from two salt marshes, Rosário (Tagus estuary) and Laranjo (Ria de Aveiro), were analyzed for total Hg and $\mathrm{Al}$, and for $\mathrm{Fe}$ and $\mathrm{Mn}$ extracted with a hydroxylamine-acetic acid solution. Both areas have been contaminated by industrial discharges during the last decades. Vertical distributions of $\mathrm{Hg}$ in sediments colonized by Arthrocnemum fruticosum and Halimione portulacoides were compared to profiles in non-vegetated sediments. The same vertical distribution pattern was observed in all situations: $\mathrm{Hg}$ enriched in sediment layers with high root density. Mercury concentrations reached 9.3 and $29.1 \mathrm{nmol} \mathrm{g}^{-1}$ in Rosário, and 149.0 and $196.0 \mathrm{nmol} \mathrm{g}^{-1}$ in Laranjo. At both marshes, higher concentrations were found in sediments colonized by $H$. portulacoides. These values are one order of magnitude above the levels found in nonvegetated sediments. Mercury was enriched in sediment layers containing high concentrations of Fe extracted with a hydroxylamine-acetic acid solution, indicating the importance of $\mathrm{Fe}$ (and $\mathrm{Mn}$ ) oxides formed in the rooting sediments for the retention of anthropogenic $\mathrm{Hg}$.
\end{abstract}

Key words: mercury, sediment, salt marsh.

\section{Resumen}

Se analizaron $\mathrm{Hg}$ y Al totales, y Fe y Mn extraídos con solución hidroxilamina-ácido acético de núcleos de sedimento de los salitrales Rosario (Estuario del Tajo) y Laranjo (Ría de Aveiro) en Portugal. Ambas áreas han estado sujetas a contaminación por descargas industriales durante las últimas décadas. Se compararon las distribuciones verticales de $\mathrm{Hg}$ en sedimentos colonizados por Arthrocnemum fruticosum y Halimione portulacoides con las de sedimentos sin vegetación. En todos los casos el patrón de distribución fue el mismo: Las capas con gran densidad de raíces se encuentran enriquecidas en $\mathrm{Hg}$. Las concentraciones de $\mathrm{Hg}$ alcanzaron 9.3 y $29.1 \mathrm{nmol} \mathrm{g}^{-1}$ en Rosario, y 149.0 y $196.0 \mathrm{nmol} \mathrm{g}^{-1}$ en Laranjo. En ambos salitrales, las mayores concentraciones se encontraron en sedimentos colonizados por $H$. portulacoides. Estos valores se encuentran un orden de magnitud por encima de los niveles encontrados en sedimentos sin vegetación. Se encontró enriquecimiento de $\mathrm{Hg}$ en capas de sedimento con elevadas concentraciones de Fe extraído con solución hidroxilamina-ácido acético, lo que sugiere la importancia que tienen, para la retención del mercurio antropogénico, los óxidos de $\mathrm{Fe}$ (y Mn) que se forman en sedimentos poblados con raíces.

Palabras clave: mercurio, sedimento, salitrales. 


\section{Introduction}

Many estuarine salt marshes in the proximity of industrialized areas receive substantial quantities of anthropogenic material transported by the tidal currents, both in dissolved and particulate forms. Contaminants associated with the suspended particulate matter are trapped by vegetation (Chenhall et al., 1992) and eventually incorporated into the surface sediment of salt marshes (Orson et al., 1992). Plants, by interacting with the surrounding sediment to uptake mineral nutrients (Ernst, 1990), accumulate in their tissues metals retained in the sediments (Alberts et al., 1990). However, the amount taken up by the plants is dependent on the metal availability in the sediment, and this is modified by the root activity (Alloway et al., 1988). Mercury has a great affinity to the particulate phase (Hurley et al., 1994) and in contaminated coastal sediments, vertical profiles of its concentration commonly document the historical evolution of mercury contamination (Gobeil and Cossa, 1993). Post-depositional redistribution of the anthropogenic mercury in contaminated sediment is thus considered small with respect to the mercury in solids, and consequently the toxicity of the buried mercury is limited. Because the sediment environment in salt marshes is exceedingly complicated, with the presence of exudates and intense microbial activity in the interfacial zone between the root and the sediment (Alloway, 1990), it is pertinent to investigate the behaviour of mercury in these peculiar environments.

Ria de Aveiro and the Tagus estuary are the two most mercury-contaminated coastal systems in Portugal (Figuères et al., 1985; Hall et al., 1987). During four decades, a confined area of Ria de Aveiro (Laranjo) has received mercury rejected by a chlo-alkalis plant. Although a fraction of anthropogenic mercury is dispersed through the estuarine system (Pereira et al., 1998a), a considerable amount (25.4 tons) is stored in sediment of Laranjo Bay (Pereira et al., 1998b). Two major sources of industrial mercury were identified in the Tagus estuary (Figuères et al., 1985), the most contaminated areas being the north channel (Canário, 2000) and the channels of the lower southern part. Both estuarine systems contain extensive intertidal flat areas and salt marshes, with homogeneous stands of plants, namely Arthrocnemum fruticosum and Halimione portulacoides. The lower salt marshes of both estuaries are inundated daily by tidal action. The pore water salinity tends to follow the tidal fluctuation in the water column (Madureira, 1997), which varied from mid-salinity values during most of the year to fresh water in winter periods of heavy rain (Pereira, 1996; Vale and Sundby, 1987). The repeated flooding of intertidal flats leads to the transport of suspended sediments enriched in anthropogenic metals, such as $\mathrm{Zn}, \mathrm{Pb}$ and $\mathrm{Cu}$, to the marshes and their subsequent retention (Caçador et al., 1996). This paper reports the depth distribution of mercury concentration in salt marsh sediments of Ria de Aveiro and the Tagus estuary with different degree of contamination, and relates these profiles to below-ground biomass and reactive iron and manganese concentration in sediments.

\section{Introducción}

Muchos salitrales de estuarios próximos a zonas industrializadas reciben cantidades sustanciales de material antropogénico transportado por las corrientes de marea, tanto en forma disuelta como en partículas. Los contaminantes asociados con la materia suspendida en partículas son atrapados por la vegetación (Chenhall et al., 1992) y eventualmente se incorporan a los sedimentos superficiales de los salitrales (Orson et al., 1992). Las plantas, al interactuar con el sedimento circundante para asimilar nutrientes minerales (Ernst, 1990), acumulan en sus tejidos los metales retenidos en los sedimentos (Alberts et al., 1990). No obstante, la cantidad absorbida por las plantas depende de la disponibilidad de metal en el sedimento, la cual es modificada por la actividad de las raíces (Alloway et al., 1988). El Hg tiene una gran afinidad con la fase particulada (Hurley et al., 1994) y, en los sedimentos costeros contaminados, los perfiles verticales de su concentración comúnmente documentan la evolución histórica de la contaminación por este metal (Gobeil y Cossa, 1993). La redistribución post-deposicional del mercurio antropogénico en sedimentos contaminados es, por lo tanto, considerada pequeña en comparación con el mercurio en sólidos $\mathrm{y}$, consecuentemente, la toxicidad del $\mathrm{Hg}$ enterrado es limitada. Dado que el ambiente de los sedimentos en los salitrales es excesivamente complicado, con la presencia de exudados e intensa actividad microbiana en la interfase entre raíces y sedimento (Alloway, 1990), es pertinente investigar el comportamiento del $\mathrm{Hg}$ en estos ambientes peculiares.

La Ría de Aveiro y el Estuario del Tajo son los sistemas costeros con mayor contaminación por $\mathrm{Hg}$ en Portugal (Figuéres et al., 1985; Hall et al., 1987). Durante cuatro décadas, un área confinada de la Ría de Aveiro (Laranjo) ha recibido el mercurio desechado por una planta de cloro-álcalis. Aunque una fracción del mercurio antropogénico es dispersada a través del sistema estuarino (Pereira et al., 1998a), una cantidad considerable es almacenada en el sedimento de la Bahía Laranjo (25.4 toneladas; Pereira et al., 1998b). En el Estuario del Tajo se han identificado dos fuentes principales de mercurio industrial (Figuéres et al., 1985), siendo las áreas consideradas como más contaminadas el Canal Norte (Canario, 2000) y los canales de la parte baja al sur. Ambos sistemas estuarinos presentan amplias planicies intermareales y salitrales, con presencia homogénea de plantas, a saber, Arthrocnemum fruticosum y Halimione portulacoides. Las partes bajas de ambos salitrales se ven inundadas diariamente por efecto de las mareas. El agua intersticial tiende a seguir la fluctuación de las mareas en la columna de agua (Madureira, 1997) la cual varió de valores medios de salinidad durante la mayor parte del año hasta agua dulce en los periodos invernales de intensa precipitación pluvial (Pereira, 1996; Vale y Sundby, 1987). La inundación intermitente de las planicies intermareales conlleva al transporte de sedimentos enriquecidos con metales antropogénicos, tales como $\mathrm{Zn}, \mathrm{Pb}$ y $\mathrm{Cu}$, hacia los salitrales y su retención subsecuente (Caçador et al., 1996). 


\section{Materials and methods}

\section{Sampling}

Sediment cores were collected in two salt marshes of the Tagus estuary (Rosário) and Ria de Aveiro (Laranjo) from pure areas colonized by $A$. fruticosum and $H$. portulacoides and non-vegetated sites (fig. 1). Cores were sampled from the lower marshes that are flooded around high tide. The sampling was done in October 1999 (Laranjo) and in February 2000 (Rosário) with PVC sediment cores of 7-cm diameter down to around 30 to $60 \mathrm{~cm}$. Sediment cores were sliced in loco. In the Tagus, the vertical resolution was $1 \mathrm{~cm}$ until the rooting zone and then every $5 \mathrm{~cm}$, and non-vegetated sediments were separated in layers of $0-5,5-15,25-35$ and $35-45 \mathrm{~cm}$. All sediments from Ria de Aveiro were sliced in 5-cm intervals. After slicing, sediment samples were stored in plastic vials until the top in order to minimize the oxidation effect due to the presence of air bubbles. In duplicate cores, temperature, redox potential and $\mathrm{pH}$ were measured in loco using a $\mathrm{pH} / \mathrm{mV}$ meter. The $\mathrm{pH}$ was measured after a short period of stabilization and redox potential was allowed to equilibrate for $15 \mathrm{~min}$.

\section{Grain size and sample preparation}

The fraction of fine particles in each sediment layer was determined by wet sieving with a $63-\mu \mathrm{m}$ mesh. Before sieving, a portion of each sediment layer was oven-dried at $70^{\circ} \mathrm{C}$ for

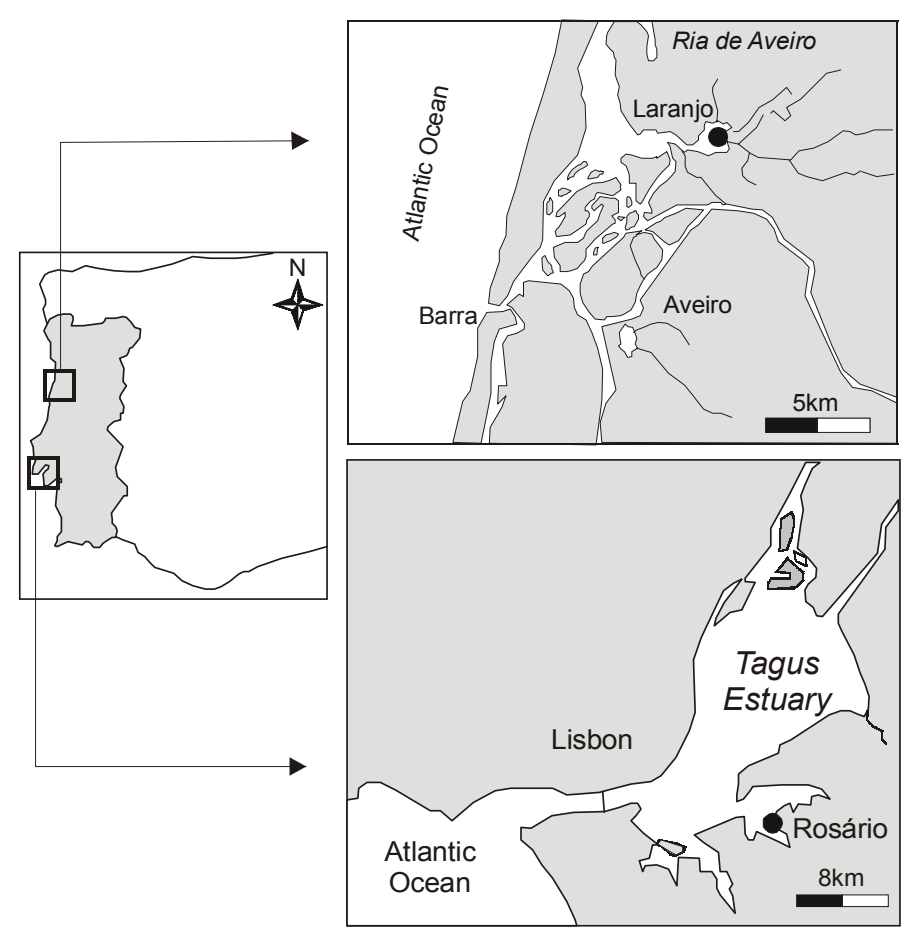

Figure 1. The sampling sites at Ria de Aveiro (Laranjo) and the Tagus Estuary (Rosário).

Figura 1. Sitios de muestreo en la Ría de Aveiro (Laranjo) y el Estuario del Tajo (Rosario).
Este artículo reporta la distribución de la concentración de $\mathrm{Hg}$ con la profundidad en los sedimentos de los salitrales de la Ría de Aveiro y el Estuario del Tajo con diferentes grados de contaminación, y relaciona estos perfiles con la biomasa subterránea y con la concentración de hierro y manganeso reactivos en los sedimentos.

\section{Materiales y métodos}

\section{Toma de muestras}

Se recolectaron núcleos de sedimento en dos salitrales, uno del Estuario del Tajo (Rosario) y el otro de la Ría de Aveiro (Laranjo), de areas colonizadas por A. fruticosum y $H$. portulacoides y de areas sin vegetación (fig. 1). Los núcleos fueron extraídos de las partes bajas de los salitrales, que son inundadas durante la pleamar, en octubre de 1999 (Laranjo) y en febrero de 2000 (Rosario), con nucleadores de sedimento de PVC de $7 \mathrm{~cm}$ de diámetro hasta una profundidad de 30 a 60 $\mathrm{cm}$. Los núcleos de sedimento fueron cortados in loco. En el Tajo, la resolución vertical fue de $1 \mathrm{~cm}$ hasta la profundidad de las raíces y después cada $5 \mathrm{~cm}$, y los sedimentos sin vegetación fueron separados en capas de 0-5, 5-15, 25-35 y 35-45 cm. Todos los sedimentos de la Ría de Aveiro fueron cortados en secciones de $5 \mathrm{~cm}$. Después de ser seccionadas, las muestras de sedimento se almacenaron en viales de plástico hasta su parte superior para minimizar el efecto de la oxidación debido a la presencia de burbujas de aire. En duplicados de los núcleos se midieron, in loco, temperatura, potencial redox y $\mathrm{pH}$, utilizando un potenciómetro $\mathrm{pH} / \mathrm{mV}$. El $\mathrm{pH}$ se midió después de un período corto de estabilización, y el potencial redox se dejó equilibrar por $15 \mathrm{~min}$.

Tamaño de grano y preparación de las muestras

La fracción de partículas finas en cada capa de sedimento se determinó por tamizado húmedo con malla de $63 \mu \mathrm{m}$. Antes de ser tamizada, se secó una porción de cada capa de sedimento en un horno a $70^{\circ} \mathrm{C}$ durante $24 \mathrm{~h}$ hasta lograr peso constante, y la eliminación de raíces por tamizado grueso se realizó mediante un tamiz de nylon con luz de malla de 0.5 $\mathrm{mm}$. Después los sedimentos de cada capa se homogeneizaron y el material de las raíces fue lavado con agua desmineralizada y secados en un horno a $70^{\circ} \mathrm{C}$, hasta obtener peso constante.

Análisis del aluminio, hierro y manganeso

Las muestras de sedimento fueron digeridas con una mezcla de $\mathrm{HF}$ y agua regia a $100^{\circ} \mathrm{C}$, de acuerdo a lo descrito por Rantala y Loring (1977). Aluminio, hierro y manganeso fueron medidos en soluciones por espectrometría de absorción atómica a la flama (Perkin Elmer modelo 400). También se digirieron muestras de sedimento con $20 \mathrm{~cm}^{3}$ de cloruro de hidroxilamonio $\left(0.4 \mathrm{~mol} \mathrm{~L}^{-1}\right.$ en una solución de ácido acético al $25 \%$ ) por $6 \mathrm{~h}$ a temperatura ambiente (Chester y Hughes, 
$24 \mathrm{~h}$ until constant weight and cleaned of roots by coarse sieving using a nylon sieve of $0.5-\mathrm{mm}$ mesh size. Sediments of each layer were then homogenized and the root material washed with demineralized water and oven-dried to constant weight at $70^{\circ} \mathrm{C}$.

Analysis of aluminium, iron and manganese

Sediment samples were digested with a mixture of HF and aqua regia at $100^{\circ} \mathrm{C}$ according to the procedure described in Rantala and Loring (1977). Aluminium, iron and manganese were measured in the solutions by flame atomic absorption spectrometry (Perkin Elmer, model 400). Sediment samples were also digested with $20 \mathrm{~cm}^{3}$ of hydroxylammonium chloride $\left(0.4 \mathrm{~mol} \mathrm{~L}^{-1}\right.$ in $25 \%$ acetic acid solution) for $6 \mathrm{~h}$ at room temperature (Chester and Hughes, 1967). Iron and manganese concentrations in the digests were determined.

\section{Analysis of mercury}

For mercury determination, acid digestion of the sediments was carried out in duplicate by adding $50 \mathrm{~mL}$ of $4 \mathrm{~mol} \mathrm{~L}^{-1}$ $\mathrm{HNO}_{3}$ to an accurately weighed aliquot of sample $(0.5-1 \mathrm{~g})$ in a borosilicate glass beaker covered with a watch glass (Pereira et al., 1998a; Ramalhosa, 2002). The digest was heated in a sand bath for $2 \mathrm{~h}$. Between 0.5 and $1 \mathrm{~g}$ of below-ground biomass was acid digested by a mixture of $\mathrm{HNO}_{3}$ and $\mathrm{H}_{2} \mathrm{SO}_{4}$ (3:2) (Cajander and Ihantola, 1984) in erlenmeyers, which were covered with a watch glass and then put in a sand bath for $4 \mathrm{~h}$ at $60^{\circ} \mathrm{C}$. The total mercury in the acid extracts of sediments and biological samples was determined by cold-vapour atomic absorption spectrometry, using a Perkin-Elmer, model 3030B, coupled with a MHS 20 Perkin-Elmer hydride system, with tin chloride as the reducing agent. The system was calibrated with acidified mercury standards. The detection limit for mercury was $50 \mathrm{ng} \mathrm{\textrm {L } ^ { - 1 }}$. The accuracy and precision of the mercury determination method for sediment and root samples was evaluated using the estuarine sediment reference material CRM 277 and the biological reference material BCR 60 . The values obtained were: $1.73 \pm 0.03 \mu \mathrm{g} \mathrm{g}^{-1}$ (certified value $1.77 \pm 0.06 \mu \mathrm{g} \mathrm{g}^{-1}$ ) and $0.32 \pm 0.02 \mu \mathrm{g} \mathrm{g}^{-1}$ (certified value $\left.0.34 \pm 0.04 \mu \mathrm{g} \mathrm{g}^{-1}\right)$.

\section{Results}

\section{Sediment characteristics}

Fine particles were the major constituents of sediments from Rosário, containing in general less than $3 \%$ of sand. The sediments from Laranjo had a larger fraction of sand, $40-65 \%$ at the vegetated site and $60-85 \%$ in non-vegetated sediments. The Al concentrations varied accordingly, being higher at Rosário (7.3-15.2\%) than at Laranjo (4.1-8.3\%). The values of $\mathrm{pH}$ were lower in the vegetated sediments of both salt marshes (6.0-6.7) than in non-vegetated sediments (6.6-7.0). The redox
1967). Se determinaron las concentraciones de hierro y manganeso en los digeridos.

\section{Análisis de mercurio}

Para la determinación de $\mathrm{Hg}$ se realizó una digestión ácida de los sedimentos por duplicado, agregando $50 \mathrm{~mL}$ de $\mathrm{HNO}_{3} 4$ mol L ${ }^{-1}$ a una alícuota de muestra $(0.5-1 \mathrm{~g})$, medida con mucha precisión, en un matraz de vidrio de borosilicato cubierto con un vidrio de reloj (Pereira et al., 1998a; Ramalhosa, 2002). El digerido se calentó en un baño de arena por 2 horas. Entre 0.5 y $1 \mathrm{~g}$ de biomasa subterránea fue digerida en una mezcla de $\mathrm{HNO}_{3}$ y $\mathrm{H}_{2} \mathrm{SO}_{4}$ (3:2) (Cajander e Ihantola, 1984) en matraces Erlenmeyer que se cubrieron con vidrios de reloj y fueron puestos en un baño de arena por 4 horas a $60^{\circ} \mathrm{C}$. El $\mathrm{Hg}$ total en los extractos ácidos de los sedimentos y las muestras biológicas fue determinado por espectrometría de absorción atómica de vapor frío, usando un aparato Perkin-Elmer modelo 3030B acoplado con un sistema híbrido Perkin-Elmer MHS 20, con cloruro de estaño como agente reductor. El sistema se calibró con estándares de $\mathrm{Hg}$ acidificado. El límite de detección para el $\mathrm{Hg}$ fue de $50 \mathrm{ng} \mathrm{L}^{-1}$. La exactitud y precisión del método de medición de $\mathrm{Hg}$ en las muestras de sedimentos y raíces se evaluó utilizando los materiales de referencia, estuarino CRM 277 y biológico BCR 60. Los valores obtenidos fueron: $1.73 \pm 0.03 \mu \mathrm{g} \mathrm{g}^{-1}$ (valor certificado $1.77 \pm 0.06 \mu \mathrm{g} \mathrm{g}^{-1}$ ) y $0.32 \pm 0.02 \mu \mathrm{g} \mathrm{g}^{-1}$ (valor certificado $0.34 \pm 0.04 \mu \mathrm{g} \mathrm{g}^{-1}$ ).

\section{Resultados}

\section{Características del sedimento}

El principal componente de los sedimentos de Rosario lo fueron las partículas finas que contuvieron en general menos del $3 \%$ de arena. Los sedimentos de Laranjo tuvieron una mayor fracción de arena, $40-65 \%$ en el sitio con vegetación y $60-85 \%$ en los sedimentos sin vegetación. Las concentraciones de Al variaron de la misma manera, siendo mayores en Rosario (7.3-15.2\%) que en Laranjo (4.1-8.3\%). En los sedimentos con vegetación de ambos salitrales los valores de $\mathrm{pH}$ fueron menores (6.0-6.7) que en los sedimentos sin vegetación (6.6-7.0). El potencial redox varió en amplios intervalos en los sedimentos con raíces que presentaron depósitos color café y sedimentos oscuros a su alrededor, y siempre un $\mathrm{E}_{\mathrm{H}}$ positivo $(>100 \mathrm{mV})$ en la superficie del sedimento. La temperatura de los sedimentos superiores fue relativamente uniforme con la profundidad, alrededor de $13^{\circ} \mathrm{C}$ en Laranjo (octubre) y $20^{\circ} \mathrm{C}$ en Rosario (febrero).

\section{Biomasa de raíces}

Las variaciones de la biomasa de raíces de A. fruticosum y $H$. portulacoides con la profundidad mostraron incrementos pronunciados en las capas subsuperficiales en ambos salitrales 
potential varied in broad intervals in the rooting sediments that presented brownish deposits and dark sediments in the vicinity, and $\mathrm{E}_{\mathrm{H}}$ was always positive $(>100 \mathrm{mV})$ at the sediment surface. The temperature of upper sediments was relatively uniform with depth, around $13^{\circ} \mathrm{C}$ at Laranjo (October) and $20^{\circ} \mathrm{C}$ at Rosário (February).

\section{Root biomass}

The depth variations of root biomass of $A$. fruticosum and $H$. portulacoides showed pronounced increases in sub-surface layers at the two salt marshes (fig. 2). Vegetated sediments at Laranjo presented a maximum of $22 \%$ of root biomass around $20-\mathrm{cm}$ depth, and below 40-cm values were much lower. Maximum of root biomass at Rosário occurred closer to the sediment surface. The roots of $A$. fruticosum constituted 15\% of the sediment at $3-\mathrm{cm}$ depth and less than $1 \%$ at $10-\mathrm{cm}$ depth. In the case of $H$. portulacoides, a broad maximum of $8 \%$ between 3- and 10-cm depth was found.

Vertical profiles of Fe and Mn

Concentrations of $\mathrm{Fe}$ and $\mathrm{Mn}$ extracted from colonized sediments by the hydroxylamine-acetic acid solution are (fig. 2). Los sedimentos con vegetación en Laranjo presentaron un máximo de $22 \%$ de biomasa de raíces alrededor de los 20 $\mathrm{cm}$ de profundidad, y valores mucho menores por debajo de los $40 \mathrm{~cm}$ de profundidad. El máximo de biomasa de raíces en Rosario ocurrió cerca de la superficie del sedimento. A $3 \mathrm{~cm} \mathrm{de}$ profundidad las raíces de $A$. fruticosum constituyeron $15 \%$ del sedimento, y a los $10 \mathrm{~cm}$ menos del $1 \%$. En el caso de $H$. portulacoides se encontró un amplio máximo de $8 \%$ entre 3 y $10 \mathrm{~cm}$ de profundidad.

\section{Perfiles verticales de Fe y Mn}

Las concentraciones de Fe y Mn extraídos por medio de la solución hidroxilamina-ácido acético de sedimentos colonizados, son comparables con los niveles encontrados en sedimentos sin vegetación (fig. 3). Las distribuciones verticales de las concentraciones de Fe en los núcleos con vegetación del salitral de Rosario excedieron en gran medida los valores de los sedimentos sin vegetación. En Laranjo se encontró una situación menos contrastante. En Rosario se encontraron incrementos en el Fe extraído alrededor de los $5 \mathrm{~cm}$ de profundidad


portulacoides), mientras que en Laranjo estos incrementos se encontraron alrededor de los $20 \mathrm{~cm}$ de profundidad (54 y

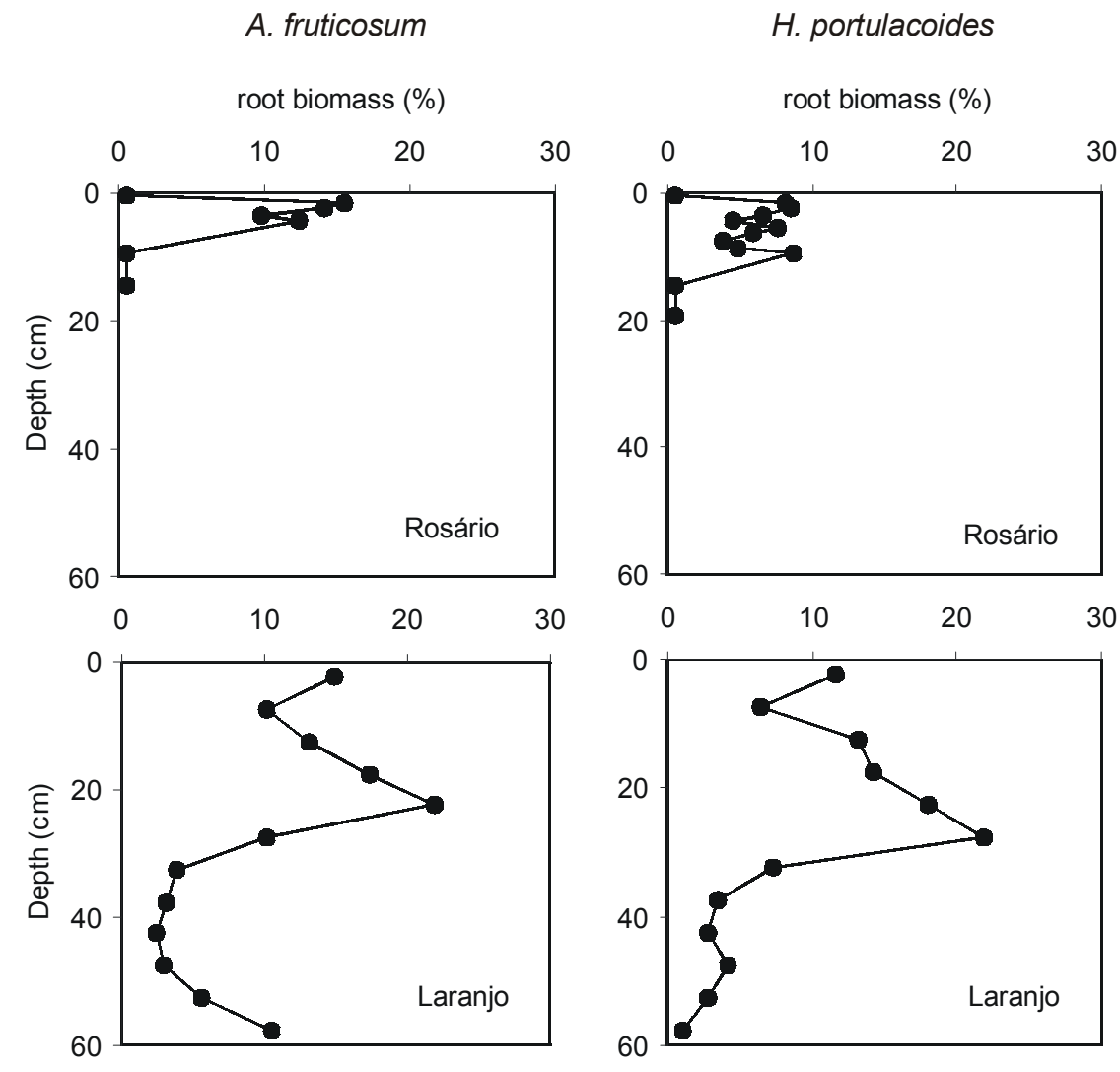

Figure 2. Vertical distribution of Arthrocnemum fruticosum and Halimione portulacoides root biomass (\%) at Rosário (Tagus estuary) and Laranjo (Ria de Aveiro).

Figura 2. Distribución vertical de la biomasa de raíces (\%) de Arthrocnemum fruticosum and Halimione portulacoides en los salitrales de Rosario (Estuario del Tajo) y Laranjo (Ría de Aveiro). 

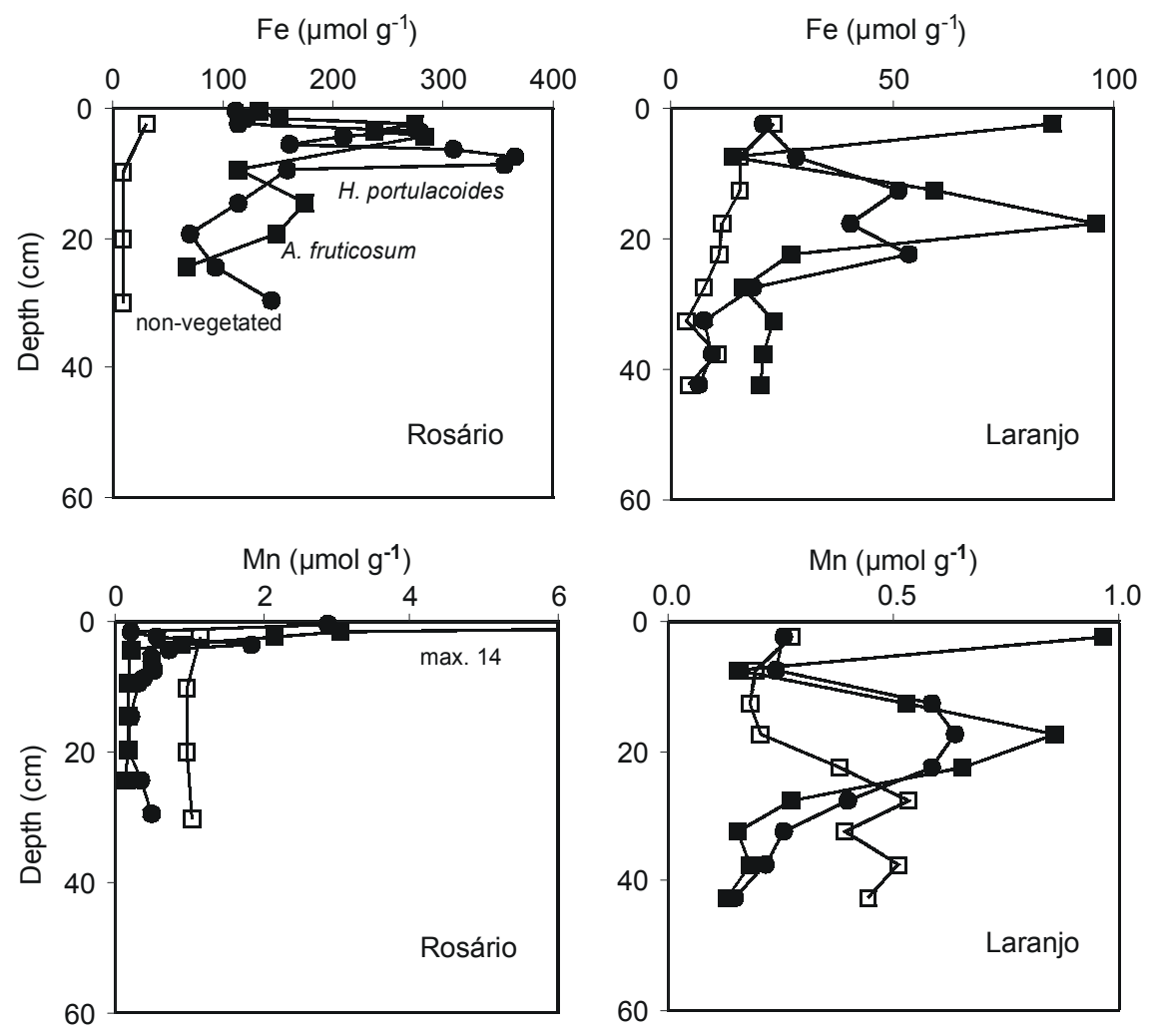

Figure 3. Vertical distributions of Fe and $\mathrm{Mn}\left(\mu \mathrm{mol} \mathrm{g}{ }^{-1}\right)$ extracted with a hydroxylamine-acetic acid solution from non-vegetated sediments and sediments colonized by Arthrocnemum fruticosum and Halimione portulacoides at Rosário (Tagus estuary) and Laranjo (Ria de Aveiro).

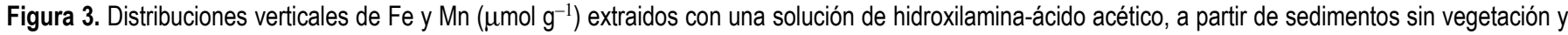
sedimentos colonizados por Arthrocnemum fruticosum and Halimione portulacoides en los salitrales de Rosario (Estuario del Tajo) y Laranjo (Ría de Aveiro).

compared to levels found in non-vegetated sediments (fig. 3). The vertical distributions of $\mathrm{Fe}$ concentrations in vegetated cores from the Rosário marsh largely exceeded the values in non-vegetated sediments. A less contrasting situation was found at Laranjo. Enhancements of extracted $\mathrm{Fe}$ were found at around 5-cm depth at Rosário $\left(284 \mu \mathrm{mol} \mathrm{g}{ }^{-1}\right.$ in A. fruticosum and $365 \mu \mathrm{mol} \mathrm{g}^{-1}$ in $H$. portulacoides) and at around $20-\mathrm{cm}$

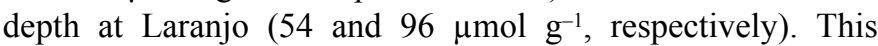
distribution pattern contrasts with the depth profiles recorded in non-vegetated sediments, with concentrations decreasing progressively with depth (fig. 3). Vegetated cores from Laranjo also showed a sub-surface enrichment of Mn, with a maximum of $0.64 \mu \mathrm{mol} \mathrm{g}^{-1}$ for A. fruticosum and $0.86 \mu \mathrm{mol} \mathrm{g}^{-1}$ for $H$. portulacoides. At Rosário, enhancement $\left(1.83 \mu \mathrm{mol} \mathrm{g}^{-1}\right)$ was only observed in sub-surface layers of $H$. portulacoides, but non-vegetated sediments generally contained higher extracted Mn.

The ratio between extractable and total $\mathrm{Fe}$ was higher in the same sub-surface layers, with maximum of $39 \%$ at Rosário and $16 \%$ at Laranjo. In non-vegetated sediments, the fraction of extractable Fe was lower (maximum 6\%) and decreased with depth until 1\%. At the sediment surface of the Rosário marsh, most of Mn (maximum 98\%) was extracted with the hydroxylamine solution, whereas at Laranjo, a slight increment was observed in sub-surface layers.

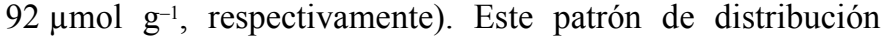
contrasta con los perfiles de profundidad registrados en sedimentos sin vegetación, en los que las concentraciones disminuyen progresivamente con la profundidad (fig. 3). Los núcleos con vegetación de Laranjo mostraron también un enriquecimiento subsuperficial de $\mathrm{Mn}$, con un máximo de

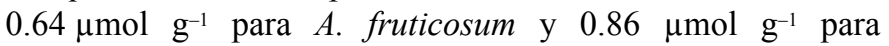
H. portulacoides. En Rosario sólo se observó enriquecimiento $\left(1.83 \mu \mathrm{mol} \mathrm{g}^{-1}\right)$ en las capas subsuperficiales de H. portulacoides, pero en general los sedimentos sin vegetación contuvieron más Mn extraíble.

La proporción entre Fe total y extraíble fue mayor en las mismas capas subsuperficiales, con un máximo de $39 \%$ en Rosario y $16 \%$ en Laranjo. En sedimentos sin vegetación la fracción de $\mathrm{Fe}$ extraíble fue menor (máximo 6\%) y disminuía con la profundidad hasta $1 \%$. En la superficie del sedimento del salitral de Rosario la mayor parte del Mn (máximo 98\%) se extrajo con la solución de hidroxilamina, mientras que en Laranjo se observó un ligero enriquecimiento en las capas subsuperficiales.

\section{Perfiles verticales de $\mathrm{Hg}$}

Los perfiles verticales de la proporción $\mathrm{Hg} / \mathrm{Al}$ en los sedimentos de ambos salitrales colonizados por H. portulacoides y 




Figure 4. Vertical distributions of $\mathrm{Hg} / \mathrm{Al}$ ratio in non-vegetated sediments and in sediments colonized by Arthrocnemum fruticosum and Halimione portulacoides at Rosário (Tagus estuary) and Laranjo (Ria de Aveiro).

Figura 4. Distribuciones verticales de la proporción $\mathrm{Hg} / \mathrm{Al}$ en sedimentos sin vegetación y sedimentos colonizados por Arthrocnemum fruticosum and Halimione portulacoides en los salitrales de Rosario (Estuario del Tajo) y Laranjo (Ría de Aveiro).

\section{Vertical profiles of $\mathrm{Hg}$}

The vertical profiles of $\mathrm{Hg} / \mathrm{Al}$ ratio in sediments from the two salt marshes colonized by $H$. portulacoides and $A$. fruticosum are compared to those found in non-vegetated sediments (fig. 4). Clearly, profiles in vegetated sediments differed considerably from those recorded in non-vegetated areas, and that resulted mainly from the higher levels of total $\mathrm{Hg}$ in rooting sediments. Surface layers of non-vegetated sediments at Rosário contained $5 \mathrm{nmol} \mathrm{g}^{-1}$ and values decreased with depth. Otherwise, the vegetated sediments presented higher $\mathrm{Hg} / \mathrm{Al}$ ratios in sub-surface layers: $[\mathrm{Hg}]=29.1 \mathrm{nmol} \mathrm{g}^{-1}$ around $6 \mathrm{~cm}$ in the case of $H$. portulacoides and $[\mathrm{Hg}]=9.3 \mathrm{nmol} \mathrm{g}^{-1}$ at $10 \mathrm{~cm}$ for $A$. fruticosum. At Laranjo, both non-vegetated and vegetated sediments presented peak values at around $15 \mathrm{~cm}$, but the $\mathrm{Hg}$ concentrations were one order of magnitude higher in the rooting sediments, $149.0 \mathrm{nmol} \mathrm{g}^{-1}$ (A. fruticosum) and $196.0 \mathrm{nmol} \mathrm{g}^{-1}$ (H. portulacoides).

\section{Discussion}

The study of $\mathrm{Hg}$ in the Tagus estuary and Ria de Aveiro is of particular importance due to the high levels found in sediments of confined areas (Figuères et al., 1985; Pereira et al., 1998a). In general, $\mathrm{Hg}$ profiles in coastal sediments reflect mainly the historical evolution of $\mathrm{Hg}$ input to the system (Klein and Goldberg, 1970; Breteler et al., 1984), and only a small fraction is recycled within the sediments (Gobeil and Cossa, 1993; Gagnon et al., 1997) or released across the sediment-water interface when oxygen in near-bottom water is depleted (Covelli et al., 1999). Results obtained in our study point to an intense redistribution of anthropogenic $\mathrm{Hg}$ in salt marsh sediments. Mercury is highly incorporated in colonized sediments and retention occurs mainly in the rooting sediment layers. This pattern was observed in sediments of two marshes with different grain size, different levels of $\mathrm{Hg}$ and colonized by two salt marsh plants eventually at different age stages. The
A. fruticosum se comparan con los encontrados en sedimentos sin vegetación (fig. 4). Evidentemente, los perfiles de los sedimentos con vegetación difirieron considerablemente de los registrados en áreas sin vegetación, y esto fue principalmente el resultado de los mayores niveles de $\mathrm{Hg}$ total en los sedimentos con raíces. Las capas superficiales de los sedimentos sin vegetación en el Rosario contuvieron $5 \mathrm{nmol} \mathrm{g}^{-1}$ y los valores disminuyeron con la profundidad. Por lo contrario, los sedimentos con vegetación presentaron mayores proporciones $\mathrm{Hg} / \mathrm{Al}$ en las capas subsuperficiales: $[\mathrm{Hg}]=29.1 \mathrm{nmol} \mathrm{g}^{-1}$ alrededor de los $6 \mathrm{~cm}$ de profundidad en el caso de H. portulacoides y $[\mathrm{Hg}]=9.3 \mathrm{nmol} \mathrm{g^{-1 }}$ a $\operatorname{los} 10 \mathrm{~cm}$ para A. fruticosum. En Laranjo, tanto los sedimentos con vegetación como los provenientes de zonas que no la presentaban mostraron valores máximos alrededor de los $15 \mathrm{~cm}$, pero las concentraciones de mercurio fueron un orden de magnitud mayores en los sedimentos con raíces, esto es, $149.0 \mathrm{nmol} \mathrm{g}^{-1}$ (A. fruticosum) y $196.0 \mathrm{nmol} \mathrm{g}^{-1}$ (H. portulacoides).

\section{Discusión}

El estudio del $\mathrm{Hg}$ en el Estuario del Tajo y en la Ría de Aveiro es de particular importancia debido a los altos niveles encontrados en los sedimentos de áreas confinadas (Figuéres et al., 1985; Pereira et al., 1998a). En general, los perfiles de mercurio en los sedimentos costeros reflejan principalmente la evolución histórica del aporte de mercurio al sistema (Klein y Goldberg, 1970; Breteler et al., 1984), y sólo una pequeña fracción de ellos es reciclada dentro de los sedimentos (Gobeil y Cossa, 1993; Gagnon et al., 1997) o liberados a través de la interfase sedimento-agua cuando se agota el oxígeno cerca del fondo (Covelli et al., 1999). Los resultados obtenidos en nuestro estudio indican una intensa redistribución del mercurio antropogénico en los sedimentos de los salitrales. El mercurio es ampliamente incorporado en los sedimentos colonizados y la retención se da principalmente en las capas de sedimento en las que hay raíces. Este patrón se observó en los sedimentos de 

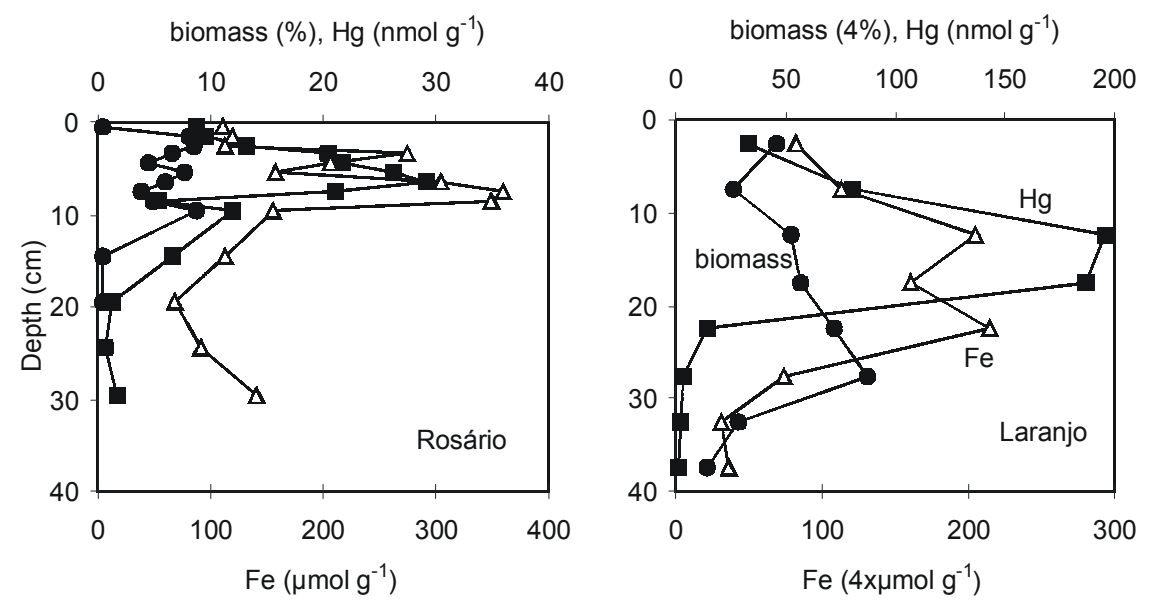

Figure 5. Vertical distributions of below-ground biomass (\%), extractable $\mathrm{Fe}\left(\mu \mathrm{mol} \mathrm{g}{ }^{-1}\right)$ and total $\mathrm{Hg}$ $\left(\mathrm{nmol} \mathrm{g}^{-1}\right)$ in sediments from Rosário and Laranjo colonized by Halimione portulacoides.

Figura 5. Distribuciones verticales de biomasa bajo tierra (\%), Fe extraíble $\left(\mu \mathrm{mol} \mathrm{g}{ }^{-1}\right)$ y Hg total $\left(\mathrm{nmol} \mathrm{g}{ }^{-1}\right)$ en sedimentos de Rosario y Laranjo colonizados por Halimione portulacoides.

incorporation was more efficient in sediments colonized by H. portulacoides than by $A$. fruticosum. This process was better observed in the most contaminated area (Laranjo); the intensity of $\mathrm{Hg}$ peaks exceeding the values registered in subtidal sediments that document the period of higher industrial discharges (Pereira et al., 1998a).

Previous studies in the Tagus salt marshes showed that release of $\mathrm{O}_{2}$ by the roots (Caetano and Vale, in press) oxidizes metal sulphides (Madureira et al., 1997) and precipitates Fe oxides near the roots (Vale, 1990; Sundby et al., 1998). High concentrations of $\mathrm{Fe}$ extracted by the hydroxylamine acid solution in the sediments containing higher root biomass, or in contiguous layers, are in line with those findings. Iron oxides (and Mn oxides in the case of Laranjo) should constitute the majority of the precipitates, although metals weakly bound to other sediment phases could also be removed by the hydroxylamine solution (Tessier et al., 1979). Besides radial transport of solutes towards the roots by molecular diffusion induced by the concentration gradient, high percentage of $\mathrm{Fe}$ in oxide forms is favoured by the root water uptake. This movement brings the pore water solutes to the proximity of the roots, namely nutrients, Fe (II), dissolved mercury and other trace elements.

The lack of correlations between values of root biomass, extractable $\mathrm{Fe}$ and total $\mathrm{Hg}$ resulted from the fact that precipitates of $\mathrm{Fe} / \mathrm{Mn}$ and $\mathrm{Hg}$ concentrations were not always maximum at layers of higher root biomass (fig. 5). The simplest plausible explanation is smaller roots, with larger active surface areas, delivering occasionally more $\mathrm{O}_{2}$ to the sediment than larger roots (higher biomass), and that causes precipitation of higher quantities of $\mathrm{Fe}$. Maximum of total $\mathrm{Hg}$ above the Fe-oxide peak appears to be related to water uptake by roots from upper sediment layers that are daily inundated by the tide. This creates a downward transport of dissolved constituents towards the rooting zone of sediments. Once Fe oxides are formed (Sundby et al., 1998), Hg then may be retained. Iron dos salitrales con diferentes tamaños de grano, diferentes niveles de mercurio y colonizados por dos plantas halófitas, eventualmente en diferentes estadios de edad. La incorporación fue más eficiente en sedimentos colonizados por H. portulacoides que en los habitados por A. fruticosum. Este proceso se observó más notablemente en el área más contaminada (Laranjo), en la que la intensidad de los máximos de $\mathrm{Hg}$ excedían los valores registrados en sedimentos sub-mareales que documentan el periodo de mayores descargas industriales (Pereira et al., 1998a).

Estudios previos en los salitrales del Tajo mostraron que el $\mathrm{O}_{2}$ liberado por las raíces (Caetano y Vale, en prensa) oxida los sulfuros metálicos (Madureira et al., 1997) y precipita los óxidos de hierro cerca de las raíces (Vale, 1990; Sundby et al., 1998). Las elevadas concentraciones de Fe extraídas con la solución ácida de hidroxilamina de los sedimentos con mayor biomasa de raíces, o en las capas contiguas, dan indicios en este sentido. Los óxidos de Fe (y los de Mn en Laranjo) deben constituir la mayoría de los precipitados, aunque también pudieron haber sido extraídos por la solución de hidroxilamina algunos metales débilmente ligados a otras fases de los sedimentos (Tessier et al., 1979). Además del transporte radial de solutos hacia la raíces por la difusión molecular inducida por el gradiente de concentración, un elevado porcentaje de $\mathrm{Fe}$ en forma de óxido es propiciado por el consumo de agua por las raíces. Este movimiento acerca los solutos de las aguas intersticiales a las raíces, entre ellos nutrientes, Fe(II), mercurio disuelto y otros elementos traza.

La falta de correlación entre los valores de biomasa de raíces, Fe extraíble y $\mathrm{Hg}$ total resultó del hecho de que los precipitados de $\mathrm{Fe} / \mathrm{Mn}$ y las concentraciones de $\mathrm{Hg}$ no siempre presentaron valores máximos en las capas de mayor biomasa de raíces (fig. 5). La explicación plausible más sencilla consiste en que las raíces más pequeñas, con mayor área superficial activa, envían ocasionalmente más $\mathrm{O}_{2}$ al sedimento que las raíces más largas (biomasa mayor), y esto causa la 
oxides, which are important scavengers of $\mathrm{Hg}$ (Jenne, 1968), thus appear to act as a barrier to the dissolved Hg. At Laranjo, it was not possible to discern whether Mn oxides have a similar role due to the parallelism of $\mathrm{Fe}$ and $\mathrm{Mn}$ profiles. The influence of precipitation of $\mathrm{Fe}$ and $\mathrm{Mn}$ on retention of $\mathrm{Hg}$ is in line with the explanation for the mobility of $\mathrm{Hg}$ in the upper contaminated sediments of Saguenay Fjord, Canada (Gobeil and Cossa, 1993).

It is noticeable that these results were obtained in winter and autumn, since $\mathrm{Fe}$ precipitates in other salt marshes of North Europe and North America are consumed in winter due to reduction of plant activity (Mendelssohn et al., 1995; Kostka and Luther, 1995). This is due to the fact that salt marsh plants in the Tagus estuary have a very short period of dormancy or remain active in winter (Catarino and Caçador, 1981). Oxidative conditions tend to stand the entire year and this creates a progressive incorporation of $\mathrm{Hg}$ onto $\mathrm{Fe}$ oxides.

\section{References}

Alberts, J.J., Price, M.T. and Kania, M. (1990). Metal concentrations in tissues of Spartina alterniflora (Loisel) and sediments of Georgia salt marshes. Est. Coast. Shelf Sci., 30: 4-58.

Alloway, B.J. (1990). Soil processes and the behaviour of metals. In: B.J. Alloway (ed.), Heavy Metals in the Soils. John Wiley and Sons, London, pp. 7-27.

Alloway, B.J., Thornton, L., Smart, G., Sherlock, J.C. and Quinn, M.J. (1988). Metal availability. Sci. Tot. Environ., 75: 41-69.

Breteler, R.J., Bowen, V.T., Schneider, D.L. and Henderson, R. (1984). Sedimentological reconstruction of recent pattern of mercury pollution in the Niagara River. Environ. Sci. Tech., 18: 404-409.

Caçador, I., Vale, C. and Catarino, F. (1996). Accumulation of Zn, Pb, $\mathrm{Cu}$ and $\mathrm{Ni}$ in sediments between roots of the Tagus estuary salt marshes, Portugal. Estuar. Coast. Shelf Sci., 42: 393-403.

Caetano, M. and Vale, C. Trace-elemental composition of seston and plankton along the Portuguese coast. Mar. Chem. (in press).

Cajander, V.R. and Ihantola, R. (1984). Mercury in some higher aquatic plants and plankton in the estuary of the River Kokemaenjoki, southern Finland. Ann. Bot. Fennici, 21: 151-156.

Canário, J. (2000). Mercúrio em sedimentos contaminados e águas intersticiais da Cala do Norte do estuário do Tejo. M.Sc. thesis, Universidade Nova de Lisboa, Portugal, 98 pp.

Catarino, F.M. and Caçador, M.I. (1981). Produção de biomassa e estratégia de desenvolvimento em Spartina maritima e outros elementos da vegetação dos sapais do estuário do Tejo. Bol. Soc. Broteriana, 2a sér. 54: 384-403.

Chenhall, B.E., Yassini, I. and Jones, B.J. (1992). Heavy metal concentration in lagoonal saltmarsh species, Ilhawarra region, southeastern Australia. Sci. Tot. Environ., 125: 203-225.

Chester, R. and Hughes, M.J (1967). A chemical technique for the separation of ferromanganese minerals, carbonate minerals and adsorbed trace metals from pelagic sediments. Chem. Geol., 2: 249-262.

Covelli, S., Faganeli, J., Horvat, M. and Brambati, A. (1999). Porewater distribution and benthic flux measurements of mercury and methylmercury in the Gulf of Trieste. Estuar. Coast. Shelf Sci., 48: 415-428. precipitación de mayores cantidades de Fe. El máximo de $\mathrm{Hg}$ total encima del de óxido de Fe parece estar relacionado con el consumo de agua por las raíces de las capas superiores de sedimento que son inundadas diariamente por la marea. Esto crea un transporte hacia abajo de componentes disueltos hacia la zona del sedimento donde están las raíces. Una vez que se forman los óxidos de Fe (Sundby et al.,1998) el $\mathrm{Hg}$ puede entonces ser retenido. Los óxidos de Fe, que son importantes secuestradores de Hg (Jenne, 1968), aparentemente actúan como una barrera para el $\mathrm{Hg}$ disuelto. En Laranjo no fue posible discernir si los óxidos de Mn juegan un papel similar debido al paralelismo de los perfiles de Fe y Mn. La influencia de la precipitación del hierro y manganeso en la retención del $\mathrm{Hg}$ concuerda con la explicación de la movilidad del $\mathrm{Hg}$ en los sedimentos superiores contaminados del Fiordo Saguenay, en Canadá (Gobeil y Cossa, 1993).

Es notable que estos resultados fueran obtenidos en invierno y otoño, dado que los precipitados de hierro en otros salitrales del norte de Europa y de Norteamérica se consumen durante el invierno debido a la reducción de la actividad vegetal (Mendelssohn et al., 1995; Kostka y Luther, 1995). Esto se debe al hecho de que las plantas halófitas en el Estuario del Tajo tienen un periodo de hibernación muy corto, o bien permanecieron activas durante el invierno (Catarino y Caçador, 1981). Las condiciones oxidantes tienden a prolongarse a lo largo de todo el año, por lo que se crea una incorporación progresiva del $\mathrm{Hg}$ a los óxidos de $\mathrm{Fe}$.

Traducido al español por Manuel Gardea-Ojeda.

Ernst, W.H.O. (1990). Ecophysiology of plants in waterlogged and flooded environments. Aquat. Bot., 38: 73-90.

Figuères, G., Martin, J.M., Meybeck, M. and Seyler, P. (1985). A comparative study of mercury contamination in the Tagus Estuary (Portugal) and major French estuaries (Gironde, Loire, Rhône). Est. Coast. Shelf. Sci., 20: 183-203.

Gagnon, C., Pelletier, É. and Mucci, A. (1997). Behaviour of anthropogenic mercury in coastal marine sediments. Mar. Chem., 59: 159-176.

Gobeil, C. and Cossa, D. (1993). Mercury in sediments and sediment pore water in the Laurentian Trough. Can. J. Fish. Aquat. Sci., 50: 1794-1800.

Hall, A., Duarte, A.C., Caldeira, M.T.M. and Lucas, M.F.B. (1987). Sources and sinks of mercury in the coastal lagoon of Aveiro, Portugal. Sci. Tot. Environ., 64(1-2): 75-87.

Hurley, J.P., Watras, J.C. and Bloom, N.S. (1994). Distribution and flux of particulate mercury in four stratified seepage lakes. In: C. Watras and W. Hunckabee (eds.), Mercury Pollution: Integration and Synthesis. Lewis Publishers, California, $726 \mathrm{pp}$.

Jenne, E.A. (1968). Controls of $\mathrm{Mn}, \mathrm{Fe}, \mathrm{Co}, \mathrm{Ni}, \mathrm{Cu}$ and $\mathrm{Zn}$ concentrations in soils and water: The significant role of hydrous Mn and Fe oxides. In: R.F. Gould (ed.), Trace Inorganics in Water. Adv. Chem. Ser., 73. Am. Chem. Soc. Washington, DC, pp. 337 387.

Klein, D.H. and Goldberg, E.D. (1970). Mercury in the marine environment. Environ. Sci. Tech., 4: 765-768. 
Kostka, J.E. and Luther III, G.W. (1995). Seasonal cycling of Fe in saltmarsh sediments. Biogeochemistry, 29: 159-181.

Madureira, M.J. (1997). Biogeoquímica do enxofre em sedimentos de sapais. Efeitos na química do ferro e do manganês. Ph.D. thesis, Universidade Técnica de Lisboa, Instituto Superior Técnico, Portugal, $219 \mathrm{pp}$.

Madureira, M.J., Vale, C. and Simões-Gonçalves, M.L. (1997). Effect of plants on sulphur geochemistry in the Tagus salt-marshes sediments. Mar. Chem., 58: 27-37.

Mendelssohn, I.A., Kleiss, B.A. and Wakeley (1995). Factors controlling the formation of oxidized root channels: A review. Wetlands, 15: 37-46.

Orson, R.A., Simpson, R.L. and Good, R.E. (1992). A mechanism for the accumulation and retention of heavy metals in tidal freshwater marshes of the upper Delaware River Estuary. Estuar. Coast. Shelf Sci., 34: 171-186.

Pereira, M.E. (1996). Distribuição, Reactividade e transporte do Mercúrio na Ria de Aveiro. Ph.D. thesis, Universidade de Aveiro, Portugal, 284 pp.

Pereira, M.E., Duarte, A.C., Millward, G.E., Vale, C. and Abreu, S.N., (1998a). Tidal export of particulate mercury from the most contaminated area of Aveiro's Lagoon, Portugal. Sci. Tot. Environ., 213: 157-163.

Pereira, M.E., Duarte, A.C., Millward, G.E., Abreu, S.N. and Vale, C. (1998b). An estimation of industrial mercury stored in sediments of a confined area of the Lagoon of Aveiro (Portugal). Wat. Sci. Tech., 37(6-7): 125-130.

Ramalhosa, E. (2002). Mercúrio na Ria de Aveiro: associações, reactividade e especiação. Ph.D. thesis, Universidade de Aveiro, Portugal, $353 \mathrm{pp}$.

Rantala, R.T.T. and Loring, D.H. (1977). A rapid determination of 10 elements in marine suspended particulate matter by atomic absorption. Atom. Absorp. News, 16: 51-52.

Sundby, B., Vale, C., Caçador, I., Catarino, F., Madureira, M.J. and Caetano, M. (1998). Metal-rich concretions on the roots of salt marsh plants: Mechanism and rate of formation. Limnol. Oceanogr., 43(2): 245-252.

Tessier, A., Campbell, P.G.C. and Bisson, M. (1979). Sequential extraction procedure for the speciation of particulate trace metals. Anal. Chem., 51(7): 844-851.

Vale, C. (1990). Temporal variations of particulate metals in the Tagus River Estuary. Sci. Tot. Environ., 97/98: 137-154. 